\title{
Facial Bone
}

National Cancer Institute

\section{Source}

National Cancer Institute. Facial Bone. NCI Thesaurus. Code C63706.

Any bone that contributes to the facial structures, except those bones that are part of the braincase. 